\title{
EFFECT OF BENEMID (p-[di-n-PROPYLSULFAMYL]-BENZOIC ACID) ON URATE CLEARANCE AND OTHER DISCRETE RENAL FUNCTIONS IN GOUTY SUBJECTS ${ }^{1}$
}

\author{
By JONAS H. SIROTA, T'SAI FAN YU, AND ALEXANDER B. GUTMAN \\ (From the First Medical Service, The Mount Sinai Hospital, and the Department of Medicine, \\ Columbia University College of Physicians and Surgeons, New York, N. Y.)
}

(Submitted for publication March 26, 1952; accepted April 28, 1952)

B e n e mi d ， ( -[di-n-propylsulfamyl]-benzoic acid), is a potent inhibitor of the renal tubular transport systems responsible for tubular secretion of the penicillins (1-3), p-aminohippurate (1), phenolsulfonphthalein (1) and p-aminosalicylic acid (4). It was initially introduced as an agent more effective than carinamide in sustaining high therapeutic blood levels of penicillin and p-aminosalicylic acid.

Benemid also is a potent uricosuric agent, of low toxicity (5). Gutman and $Y \ddot{u}(6)$, in studies on 39 patients with chronic gout maintained on a low purine, restricted protein diet, found that Benemid consistently caused a rapid and marked increase in urinary urate excretion and a sharp decline in serum urate levels. The mean rise in urinary urate excretion in the first week of Benemid administration was $67 \%, 52 \%$ and $46 \%$ with daily doses of $2 \mathrm{gm}$., $1 \mathrm{gm}$. or $0.5 \mathrm{gm}$., respectively, resulting in corresponding falls in serum urate of $42 \%, 33 \%$ and $27 \%$. Talbott, Bishop, Norcross, and Lockie (7) have reported similar results. The drug appears to have an important place in the management of chronic gout (8).

In the present study the renal mechanisms whereby the uricosuric action of Benemid is effected have been investigated. Simultaneous renal clearance studies of urate, inulin or endogenous creatinine, p-aminohippurate, sodium, potassium and chloride were carried out in 10 male gouty subjects before and after oral administration of $2 \mathrm{gm}$. of Benemid. In some of these subjects the effects of Benemid on phosphate clearance, urinary excretion of hydrogen and ammonium ion, and on urine and blood $\mathrm{pH}$ were also

1 Supported by grants from the National Institute of Arthritis and Metabolic Diseases, National Institutes of Health, U. S. Public Health Service; the American Heart Association; and the Sarah Welt Foundation. studied. The implications of our findings in respect to the renal mechanisms for regulation of urate excretion by the kidneys in normal and gouty man are discussed.

\section{METHODS}

The subjects, whose ages ranged from 38 to 54 years, were all known to have had gout for several years. Only patients without overt cardiovascular and renal disease (no albuminuria, cylindruria, nitrogen retention) were used for these experiments. All had been on low purine, restricted protein $(50-80 \mathrm{gm} . / \mathrm{day})$ diets preceding study and were in the morning post-absorptive state at the time of the experiment. Water was ingested in liberal quantities to maintain urine flow rates above $4 \mathrm{ml} . / \mathrm{min}$. throughout the experiment.

After drawing blood for inulin and p-aminohippurate plasma blank values, priming and sustaining infusions of these substances in $0.89 \%$ saline were administered by means of a Bowman constant infusion pump at rates calculated to maintain plasma concentrations of inulin at 30 mg. $\%$ and p-aminohippurate at $2 \mathrm{mg} . \%$. Thirty minutes were allowed for equilibration. Bladder catheterization was then performed with multi-eyed hard rubber catheters and three 10- to 15-minute urine collections were obtained for the control clearance values. Bloods were drawn midway between the first and third clearance periods. Following the third control period $2 \mathrm{gm}$. of the drug were administered orally (19.3 to $29.5 \mathrm{mg} . / \mathrm{kg}$.). Six 20 minute post-Benemid clearance periods were then obtained. Three bloods were drawn approximately 30,70 and 110 minutes after drug administration and representative plasma concentrations of inulin, urate and p-aminohippurate were obtained by plotting the concentrations semilogarithmically against time and by extrapolating back to 2.5 minutes (approximate urine delay time) from the mid-time of each urine collection period. Bladder washouts with $20 \mathrm{ml}$. of distilled water, followed by air, effected complete emptying at the termination of each urine collection period. With slight modifications the clearance techniques employed were those recommended by Goldring and Chasis (9).

In two additional subjects simultaneous endogenous creatinine, urate, sodium, potassium and chloride clearances were obtained at 30-minute periods for two hours preceding and two hours following administration of Benemid. In this manner intravenous infusions were 
avoided and urine could be collected by spontaneous voiding.

In two gouty subjects the effects of a single $2 \mathrm{gm}$. oral dose of Benemid upon simultaneous inulin, urate, endogenous creatinine and $\mathrm{p}$-aminohippurate were studied over 24 hours. The drug was administered to these subjects following three 10 - to 20 -minute control periods, during which time urine was collected by catheter and bladder wash. Following administration of the drug, urines were collected by spontaneous voiding at two-hour intervals during the day and at two four-hour intervals at night. Intravenous infusions of inulin and p-aminohippurate were maintained for 24 hours employing the technique of Sirota, Baldwin and Villarreal (10). Two bloods were drawn during the control periods, and six at strategically spaced intervals for 24 hours after drug ingestion. In a third subject the diurnal variations of endogenous creatinine, urate, sodium, potassium and chloride clearances were studied for 48 hours preceding Benemid and for 48 hours following a single $2 \mathrm{gm}$. oral dose. This patient was hospitalized and maintained on a constant protein (50 gm.), constant salt $(3.5 \mathrm{gm}$.) diet for three days preceding the control study. Water was allowed ad lib. throughout.

TABLE I

The acute effect of oral Benemid upon the renal clearances of inulin, urate and PAH in 10 subjects with non-tophaceous gout

\begin{tabular}{|c|c|c|c|c|c|c|c|}
\hline \multirow{2}{*}{$\begin{array}{l}\text { Subject } \\
\text { Age }\end{array}$} & \multirow{2}{*}{ Period } & \multicolumn{5}{|c|}{ Renal clearances $\ddagger$} & \multirow{2}{*}{$\underset{\text { acid }}{\text { Plasma uric }}$} \\
\hline & & $\mathrm{C}_{\mathrm{IN}}$ & Curate & $\mathrm{C}_{\text {PAB }}$ & CURate/CIN & $\mathrm{C}_{\mathrm{IN}} / \mathrm{C}_{\mathrm{PAH}}$ & \\
\hline A. R. & $\begin{array}{l}\text { Control* } \\
\text { Benemid } 24.6 \mathrm{mg} . / \mathrm{kg} . \\
20 \mathrm{~min} . \\
40 \mathrm{~min} . \\
60 \mathrm{~min} . \\
80 \mathrm{~min} . \\
100 \mathrm{~min} . \\
120 \mathrm{~min} .\end{array}$ & $\begin{array}{c}\text { ml./min. } \\
100 \\
\\
103 \\
108 \\
109 \\
109 \\
116 \\
107\end{array}$ & $\begin{array}{c}\text { ml. } / \text { min. } \\
5.02 \\
\\
5.39 \\
14.5 \\
24.3 \\
25.8 \\
29.9 \\
27.3\end{array}$ & $\begin{array}{c}\text { ml. } / \min . \\
557 \\
\\
618 \\
590 \\
632 \\
455 \\
395 \\
520\end{array}$ & $\begin{array}{l}0.050 \\
0.052 \\
0.135 \\
0.223 \\
0.237 \\
0.258 \\
0.255\end{array}$ & $\begin{array}{l}0.179 \\
0.167 \\
0.183 \\
0.173 \\
0.239 \\
0.294 \\
0.205\end{array}$ & $\begin{array}{l}6.8 \\
6.6 \\
6.2\end{array}$ \\
\hline H. G. & $\begin{array}{l}\text { Control } \\
\text { Benemid } 19.3 \mathrm{mg} . / \mathrm{kg} . \\
20 \mathrm{~min} . \\
40 \mathrm{~min} . \\
60 \mathrm{~min} . \\
80 \mathrm{~min} . \\
100 \mathrm{~min} . \\
120 \mathrm{~min} .\end{array}$ & $\begin{array}{l}117 \\
131 \\
112 \\
119 \\
119 \\
113 \\
104\end{array}$ & $\begin{array}{r}8.30 \\
\\
9.00 \\
8.00 \\
18.1 \\
33.6 \\
27.2 \\
13.2\end{array}$ & $\begin{array}{l}529 \\
\\
508 \\
576 \\
638 \\
634 \\
341 \\
311\end{array}$ & $\begin{array}{l}0.071 \\
0.069 \\
0.071 \\
0.152 \\
0.282 \\
0.241 \\
0.127\end{array}$ & $\begin{array}{l}0.221 \\
0.242 \\
0.195 \\
0.187 \\
0.188 \\
0.332 \\
0.335\end{array}$ & $\begin{array}{r}11.1 \\
10.3 \\
10.3\end{array}$ \\
\hline L. G. & $\begin{array}{l}\text { Control } \\
\text { Benemid } 25.9 \mathrm{mg} . / \mathrm{kg} . \\
20 \mathrm{~min} . \\
40 \mathrm{~min} . \\
60 \mathrm{~min} . \\
80 \mathrm{~min} . \\
100 \mathrm{~min} . \\
120 \mathrm{~min} .\end{array}$ & $\begin{array}{l}119 \\
119 \\
122 \\
121 \\
115 \\
122 \\
113\end{array}$ & $\begin{array}{l}11.0 \\
11.8 \\
28.8 \\
36.7 \\
36.6 \\
40.2 \\
42.1\end{array}$ & $\begin{array}{l}610 \\
579 \\
538 \\
516 \\
463 \\
480 \\
414\end{array}$ & $\begin{array}{l}0.092 \\
\\
0.099 \\
0.236 \\
0.303 \\
0.318 \\
0.330 \\
0.373\end{array}$ & $\begin{array}{l}0.195 \\
0.220 \\
0.230 \\
0.209 \\
0.268 \\
0.214 \\
0.261\end{array}$ & $\begin{array}{r}8.1 \\
7.5 \\
6.8\end{array}$ \\
\hline H. $\underset{47}{H . \dagger}$ & $\begin{array}{l}\text { Control } \\
\text { Benemid } 27.5 \mathrm{mg} . / \mathrm{kg} . \\
20 \mathrm{~min} . \\
40 \mathrm{~min} . \\
60 \mathrm{~min} . \\
80 \mathrm{~min} . \\
100 \mathrm{~min} . \\
120 \mathrm{~min} .\end{array}$ & $\begin{array}{l}99.9 \\
92.0 \\
94.0 \\
77.7 \\
85.4 \\
67.8 \\
82.4\end{array}$ & $\begin{array}{l}9.14 \\
10.1 \\
16.3 \\
13.6 \\
31.3 \\
27.4 \\
35.3\end{array}$ & $\begin{array}{l}621 \\
640 \\
582 \\
520 \\
522 \\
388 \\
502\end{array}$ & $\begin{array}{l}0.092 \\
\\
0.110 \\
0.174 \\
0.175 \\
0.367 \\
0.404 \\
0.428\end{array}$ & $\begin{array}{l}0.161 \\
\\
0.144 \\
0.162 \\
0.149 \\
0.164 \\
0.175 \\
0.164\end{array}$ & $\begin{array}{l}7.2 \\
6.4 \\
6.2\end{array}$ \\
\hline W. L. $†$ & $\begin{array}{l}\text { Control } \\
\text { Benemid } 23.2 \mathrm{mg} . / \mathrm{kg} \text {. } \\
20 \mathrm{~min} . \\
40 \mathrm{~min} . \\
60 \mathrm{~min} . \\
80 \mathrm{~min} . \\
100 \mathrm{~min} . \\
120 \mathrm{~min} .\end{array}$ & $\begin{array}{l}137 \\
132 \\
136 \\
121 \\
130 \\
129 \\
110\end{array}$ & $\begin{array}{l}13.2 \\
13.8 \\
21.2 \\
32.0 \\
51.0 \\
51.3 \\
51.2\end{array}$ & $\begin{array}{l}623 \\
656 \\
632 \\
510 \\
504 \\
377 \\
299\end{array}$ & $\begin{array}{l}0.096 \\
0.105 \\
0.156 \\
0.265 \\
0.393 \\
0.398 \\
0.465\end{array}$ & $\begin{array}{l}0.220 \\
\\
0.201 \\
0.215 \\
0.237 \\
0.258 \\
0.343 \\
0.369\end{array}$ & $\begin{array}{l}7.8 \\
7.2 \\
6.5\end{array}$ \\
\hline
\end{tabular}

* The control clearance values represent the averages of three 10- to 15-minute urine collection periods. The control plasma urate values represent the averages of three separate determinations before administration of Benemid.

$\dagger$ Endogenous creatinine clearances were substituted for inulin clearances in these instances.

$\ddagger$ Not corrected for surface area (values in text so corrected are indicated there). 
TABLE I-Continued

\begin{tabular}{|c|c|c|c|c|c|c|c|}
\hline \multirow{2}{*}{$\begin{array}{l}\text { Subject } \\
\text { Age }\end{array}$} & \multirow{2}{*}{ Period } & \multicolumn{5}{|c|}{ Renal clearances } & \multirow{2}{*}{$\underset{\text { acid }}{\text { Plasma uric }}$} \\
\hline & & $\mathrm{C}_{\mathrm{IN}}$ & Curate & $\mathrm{CPAH}_{\mathrm{PA}}$ & Curate/Cin & $\mathrm{C}_{\mathrm{IN}} / \mathrm{C}_{\mathbf{P A H}}$ & \\
\hline & $\begin{array}{l}\text { Control } \\
\text { Benemid } 25.5 \mathrm{mg} . / \mathrm{kg} \text {. }\end{array}$ & $\begin{array}{c}\mathrm{ml} . / \mathrm{min} . \\
83.7\end{array}$ & $\begin{array}{l}m l . / \min . \\
7.68\end{array}$ & $\begin{array}{l}m l . / m i n . \\
332\end{array}$ & 0.092 & 0.253 & $\begin{array}{l}\text { mg. } \% \\
9.6\end{array}$ \\
\hline N. W. & $\begin{array}{l}20 \mathrm{~min} . \\
40 \mathrm{~min} . \\
60 \mathrm{~min} . \\
80 \mathrm{~min} . \\
100 \mathrm{~min} . \\
120 \mathrm{~min} .\end{array}$ & $\begin{array}{c}90.7 \\
92.6 \\
88.8 \\
72.0 \\
103 \\
69.4\end{array}$ & $\begin{array}{l}12.2 \\
45.7 \\
48.0 \\
39.4 \\
50.9 \\
28.7\end{array}$ & $\begin{array}{l}343 \\
328 \\
244 \\
203 \\
125 \\
355\end{array}$ & $\begin{array}{l}0.135 \\
0.493 \\
0.541 \\
0.547 \\
0.493 \\
0.413\end{array}$ & $\begin{array}{l}0.264 \\
0.282 \\
0.364 \\
0.355 \\
0.825 \\
0.195\end{array}$ & $\begin{array}{l}8.7 \\
8.5 \\
7.6\end{array}$ \\
\hline & $\begin{array}{l}\text { Control } \\
\text { Benemid } 29.5 \mathrm{mg} . / \mathrm{kg} .\end{array}$ & 76.0 & 6.62 & 485 & 0.087 & 0.157 & 6.3 \\
\hline M. M. & $\begin{array}{l}20 \mathrm{~min} . \\
40 \mathrm{~min} . \\
60 \mathrm{~min} . \\
80 \mathrm{~min} . \\
100 \mathrm{~min} . \\
120 \mathrm{~min} .\end{array}$ & $\begin{array}{l}76.6 \\
81.0 \\
84.0 \\
68.5 \\
72.4 \\
79.3\end{array}$ & $\begin{array}{l}7.50 \\
11.5 \\
14.3 \\
13.7 \\
14.1 \\
18.1\end{array}$ & $\begin{array}{l}448 \\
457 \\
434 \\
380 \\
383 \\
426\end{array}$ & $\begin{array}{l}0.098 \\
0.142 \\
0.170 \\
0.200 \\
0.195 \\
0.228\end{array}$ & $\begin{array}{l}0.171 \\
0.177 \\
0.194 \\
0.180 \\
0.189 \\
0.186\end{array}$ & $\begin{array}{l}6.5 \\
6.1 \\
5.8\end{array}$ \\
\hline & $\begin{array}{l}\text { Control } \\
\text { Benemid } 23.3 \mathrm{mg} . / \mathrm{kg} \text {. }\end{array}$ & 128 & 13.2 & 650 & 0.103 & 0.197 & 9.5 \\
\hline A. L. & $\begin{array}{l}20 \mathrm{~min} . \\
40 \mathrm{~min} . \\
60 \mathrm{~min} . \\
80 \mathrm{~min} . \\
100 \mathrm{~min} . \\
120 \mathrm{~min} .\end{array}$ & $\begin{array}{l}138 \\
124 \\
123 \\
113 \\
108 \\
116\end{array}$ & $\begin{array}{l}14.0 \\
23.0 \\
33.6 \\
31.1 \\
31.4 \\
29.6\end{array}$ & $\begin{array}{l}664 \\
584 \\
446 \\
566 \\
518 \\
524\end{array}$ & $\begin{array}{l}0.100 \\
0.184 \\
0.270 \\
0.272 \\
0.307 \\
0.252\end{array}$ & $\begin{array}{l}0.208 \\
0.213 \\
0.363 \\
0.200 \\
0.208 \\
0.221\end{array}$ & 8.0 \\
\hline & $\begin{array}{l}\text { Control } \\
\text { Benemid } 22.7 \mathrm{mg} . / \mathrm{kg} \text {. }\end{array}$ & 98.5 & 4.98 & 526 & 0.051 & 0.187 & 8.0 \\
\hline J. R. & $\begin{array}{l}20 \mathrm{~min} . \\
40 \mathrm{~min} . \\
60 \mathrm{~min} . \\
80 \mathrm{~min} . \\
100 \mathrm{~min} . \\
120 \mathrm{~min} .\end{array}$ & $\begin{array}{c}110 \\
95.8 \\
90.1 \\
95.6 \\
91.2 \\
87.9\end{array}$ & $\begin{array}{c}4.60 \\
3.79 \\
4.34 \\
4.84 \\
6.29 \\
10.4\end{array}$ & $\begin{array}{l}516 \\
489 \\
443 \\
462 \\
469 \\
432\end{array}$ & $\begin{array}{l}0.042 \\
0.040 \\
0.048 \\
0.051 \\
0.069 \\
0.118\end{array}$ & $\begin{array}{l}0.213 \\
0.196 \\
0.203 \\
0.207 \\
0.197 \\
0.203\end{array}$ & $\begin{array}{l}8.3 \\
8.1 \\
8.0\end{array}$ \\
\hline & $\begin{array}{l}\text { Control } \\
\text { Benemid } 26.2 \mathrm{mg} . / \mathrm{kg} .\end{array}$ & 75.1 & 6.32 & 316 & 0.084 & 0.238 & 13.9 \\
\hline $\mathrm{R}_{47} \mathrm{C}$. & $\begin{array}{l}20 \mathrm{~min} . \\
40 \mathrm{~min} . \\
60 \mathrm{~min} . \\
80 \mathrm{~min} . \\
100 \mathrm{~min} . \\
120 \mathrm{~min} .\end{array}$ & $\begin{array}{l}78.2 \\
76.2 \\
71.2 \\
73.0 \\
70.1 \\
67.7\end{array}$ & $\begin{array}{l}7.80 \\
12.1 \\
23.6 \\
16.6 \\
17.1 \\
20.6\end{array}$ & $\begin{array}{l}342 \\
348 \\
268 \\
251 \\
253 \\
238\end{array}$ & $\begin{array}{l}0.100 \\
0.159 \\
0.332 \\
0.228 \\
0.244 \\
0.304\end{array}$ & $\begin{array}{l}0.229 \\
0.219 \\
0.266 \\
0.291 \\
0.277 \\
0.284\end{array}$ & $\begin{array}{l}12.6 \\
12.4 \\
11.2\end{array}$ \\
\hline
\end{tabular}

Inulin in plasma and urine was determined by the method of Schreiner (11), p-aminohippurate by the method of Smith and his associates (12), "creatinine" by the method of Bonsnes and Taussky (13), phosphate by the method of Fiske and SubbaRow (14) as modified for spectrophotometry, and chloride by either the method of Schales and Schales (15) or Van Slyke and Hiller's modification of the Sendroy method (16). Sodium and potassium analyses were performed by means of the Perkin-Elmer internal standard flame photometer, Model $120 \mathrm{~A}$. Urine ammonia determinations were performed by the method of Van Slyke and Cullen (17), urine titratable acidity by the technique of Pitts and Alexander (18), and blood and urine $\mathrm{pH}$ by means of the Cambridge $\mathrm{pH}$ meter. Plasma and urine urate concen- trations were determined by a modification of the method of Buchanan, Block and Christman (19), using uricase digestion, urea cyanide-carbonate and arsenophosphotungstic acid. With this method inulin and p-aminohippurate, in the concentration ranges present in these studies, were found not to interfere with the recovery of urate from plasma and urine. For estimating filtrable plasma urate, ultrafiltrates of plasma were obtained by means of the Simms-Sanders "surge" ultrafiltration apparatus (20). In this device negative pressures are applied and rapidly varied by $10-15 \mathrm{~mm}$. $\mathrm{Hg}$ so as to remove the serum protein film which would otherwise soon occlude the surface of the collodion sac. Thus the rate of ultrafiltration is greatly increased and a minimum of urate is retained by adsorption on the protein film. 


\section{RESULTS}

Acute experiments. Table I summarizes observations on the acute effects of $2 \mathrm{gm}$. Benemid given orally on the renal clearances of inulin $\left(\mathrm{C}_{\mathrm{IN}}\right)$, urate $\left(\mathrm{C}_{\mathrm{ORATE}}\right)$ and p-aminohippurate $\left(\mathrm{C}_{\mathrm{PAH}}\right)$ in 10 gouty subjects. Despite the absence of gross manifestations of renal damage in these patients, the control $\mathrm{C}_{\mathrm{IN}}$ and $\mathrm{C}_{\mathrm{PAH}}$ values were found to be slightly to moderately depressed. Thus the mean $\mathrm{C}_{\mathrm{IN}}$ was $92.5 \mathrm{ml} . / \mathrm{min} . / 1.73 \mathrm{M}^{2}$ with a range of 73-111; the mean $\mathrm{C}_{\mathrm{PAH}}$ was 472 $\mathrm{ml} . / \mathrm{min} . / 1.73 \mathrm{M}^{2}$ with a range of $307-596$.

As indicated in Table I, Benemid in this dosage consistently caused a striking increase in $\mathrm{C}_{\text {URATE }}$ which was sustained over the two-hour period of observation. $\mathrm{C}_{\text {URATE }}$ rose from a mean control value of $8.55 \mathrm{ml} . / \mathrm{min}$. (range $4.98-13.2$ ) to peak values averaging $32.9 \mathrm{ml} . / \mathrm{min}$. (range 10.251.3). In eight of the 10 subjects this rise was apparent within 40 minutes of ingestion of the drug. In six instances an accompanying fall in plasma urate of $1 \mathrm{mg} . \%$ or more was noted by the end of two hours.

Significant changes in $\mathrm{C}_{\mathrm{IN}}$ did not occur. Consequently, the ratio $\mathrm{C}_{\mathrm{URATE}} / \mathrm{C}_{\mathrm{IN}}$ rose, from a mean control value of 0.071 (range 0.050 to 0.103 ) to peak values averaging 0.337 (range 0.118 to 0.547). In two cases (not included in Table I) in which the clearance of endogenous creatinine was used as a measure of glomerular filtration and intravenous infusions thus avoided, $\mathrm{C}_{\mathrm{DRATE}} / \mathrm{C}_{\mathrm{CR}}$ rose from control values of 0.066 and 0.046 to 0.510 and 0.252 , respectively, after Benemid. The $\mathrm{C}_{\mathrm{CR}} / \mathrm{C}_{\mathrm{IN}}$ ratio was found to average $1.03 \pm$ 0.03 before Benemid and $0.965 \pm 0.048$ after Benemid in eight gouty subjects, a correspondence which justifies use of $C_{C R}$ for $G F R$ under these circumstances.

TABLE II

The effect of oral Benemid upon the renal clearances of sodium, potassium, chloride and phosphate in gouty subjects

\begin{tabular}{|c|c|c|c|c|c|c|c|c|c|c|c|c|c|c|c|}
\hline \multirow{2}{*}{ Case } & \multicolumn{3}{|c|}{$\mathrm{C}_{\mathrm{IN}}$} & \multicolumn{3}{|c|}{$100 \times \frac{\mathrm{C}_{\mathrm{Na}}}{\mathrm{C}_{\mathrm{IN}}}$} & \multicolumn{3}{|c|}{$100 \times \frac{C_{C l}}{C_{I N}}$} & \multicolumn{3}{|c|}{$100 \times \frac{C_{K}}{C_{I N}}$} & \multicolumn{3}{|c|}{$100 \times \frac{C_{P O_{4}}}{C_{I N}}$} \\
\hline & $\underset{\text { trol }}{\text { Con- }}$ & $\begin{array}{c}\text { After } \\
\text { Benemid }\end{array}$ & $\begin{array}{c}\% \\
\text { Change }\end{array}$ & $\begin{array}{c}\text { Con- } \\
\text { trol }\end{array}$ & $\begin{array}{c}\text { After } \\
\text { Benemid }\end{array}$ & $\begin{array}{c}\% \\
\text { Change }\end{array}$ & $\begin{array}{c}\text { Con- } \\
\text { trol }\end{array}$ & $\begin{array}{c}\text { After } \\
\text { Benemid }\end{array}$ & $\begin{array}{c}\% \\
\text { Change }\end{array}$ & $\begin{array}{c}\text { Con- } \\
\text { trol }\end{array}$ & $\begin{array}{c}\text { After } \\
\text { Benemid }\end{array}$ & $\begin{array}{c}\% \\
\text { Change }\end{array}$ & $\underset{\text { trol }}{\text { Con- }}$ & After & $\begin{array}{c}\% \\
\text { Change }\end{array}$ \\
\hline R. C. & 75.1 & 72.7 & -3.3 & 4.26 & 4.15 & -2.6 & 5.51 & 5.19 & -5.8 & 20.0 & 18.7 & -6.5 & 9.64 & 9.29 & -3.6 \\
\hline L. G. & 119 & 119 & 0.0 & 2.98 & 3.66 & $+22.7 \dagger$ & 3.35 & 4.14 & $+23.6 t$ & 11.1 & 17.3 & +55.8 & 19.0 & 22.6 & +19.0 \\
\hline J. R. & 98.5 & 95.1 & -3.6 & 1.46 & 2.01 & +37.7 & 1.95 & 2.57 & +31.8 & 29.0 & 25.2 & -13.1 & 21.0 & 22.1 & +52 \\
\hline A. L. & 128 & 120 & -6.2 & 2.67 & 3.09 & $+15.9 \dagger$ & 2.19 & 2.89 & +32.0 & 22.0 & 17.6 & -20.0 & 17.0 & 14.9 & -12.3 \\
\hline H. H.* & 99.9 & 83.2 & -16.8 & 6.33 & 5.87 & -7.3 & 8.03 & 5.70 & -29.0 & 38.4 & 24.1 & -37.2 & 8.34 & 6.36 & -23.8 \\
\hline W. L.* & 137 & 126 & -8.0 & 1.98 & 2.84 & $+43.5 t$ & 1.56 & 2.18 & $+39.6 t$ & 25.8 & 24.2 & -6.2 & 10.9 & 10.9 & 0.0 \\
\hline H. G. & 117 & 113 & -3.4 & 1.71 & 1.85 & +8.2 & 2.57 & 2.62 & +2.0 & 34.7 & 31.0 & -10.7 & & & \\
\hline M. M. & 76.0 & 77.1 & +1.5 & 2.30 & 2.79 & +21.3 & 3.05 & 3.38 & +10.8 & 25.2 & 26.6 & +5.6 & & & \\
\hline A. $R$. & 100 & 108 & +8.0 & 1.05 & 2.41 & $+130 t$ & 1.64 & 3.24 & $+97.2 \dagger$ & 47.4 & 29.2 & -38.4 & & & \\
\hline N. W. & 83.7 & 86.1 & +3.0 & 3.26 & 6.76 & $+107 \dagger$ & 3.46 & 5.15 & +48.8 & 20.5 & 23.0 & +12.2 & & & \\
\hline O. G.* & 83.5 & 70.6 & -15.4 & 0.27 & 0.59 & +119 & 0.78 & 1.50 & $+92.5 t$ & 24.8 & 32.0 & +29.0 & & & \\
\hline A. R.* & 120 & 111 & -7.5 & 2.10 & 1.70 & -19.0 & 1.38 & 1.12 & -18.8 & 10.9 & 14.2 & +30.3 & & & \\
\hline $\begin{array}{l}\text { Mean } \\
\text { S.D. }\end{array}$ & & & $\begin{array}{l}-4.3 \\
\pm 2.1\end{array}$ & & & $\begin{array}{l}+39.7 \\
\pm 14.7\end{array}$ & & & $\begin{array}{l}+24.1 \\
\pm 11.4\end{array}$ & & & $\begin{array}{r}+.07 \\
\pm 8.1\end{array}$ & & & $\begin{array}{l}-2.6 \\
\pm 5.9\end{array}$ \\
\hline
\end{tabular}

The control values represent the averages of three 10- to 15-minute periods. The values after Benemid represent the averages of six 20-minute periods starting immediately after oral ingestion of $2 \mathrm{gm}$. of the drug.

* $\mathrm{C}_{\mathrm{CR}}$, endogenous creatinine clearance, used instead of $\mathrm{C}_{\mathrm{IN}}$ in these subjects.

$\dagger$ These changes considered significant $(p<.02)$. The $t$ test of significance for the $\frac{C_{\mathrm{Na}}}{C_{I N}}$ and $\frac{C_{C l}}{C_{I N}}$ ratios was applied to the six post-Benemid clearances as compared to the three control periods for each of the subjects. 


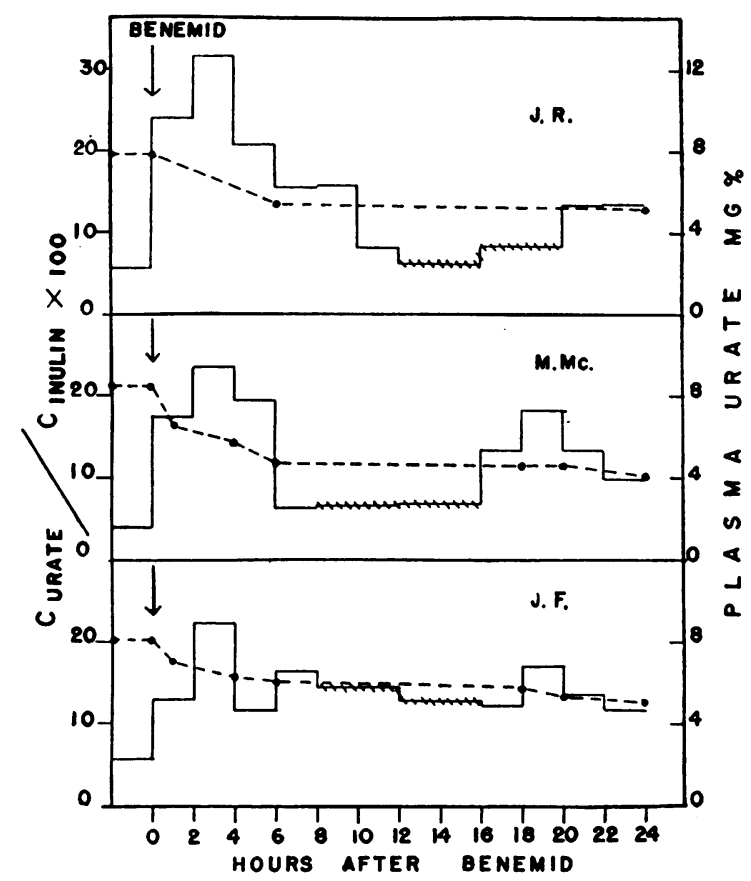

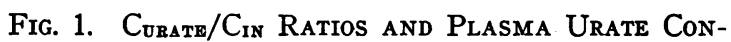
centrations in Three Subjects for 24 Hours Following a Single Oral Dose of 2 gm. Benemid (Arrow)

$C_{C R}$ was substituted for $C_{I N}$ in subject J. R. The preBenemid control $\mathrm{C}_{\mathrm{URATH}} / \mathrm{C}_{\mathrm{IN}}$ ratios represent the average of three 10- to 15-minute periods. The solid lines represent the $\mathrm{C}_{\text {URATI }} / \mathrm{C}_{\mathrm{IN}}$ ratios, the interrupted lines plasma urate concentrations and cross-hatches the sleeping hours.

There was a general moderate decline in $\mathrm{C}_{\mathbf{P A H}}$ usually evident after one hour. The clearance ratios $\mathrm{C}_{\mathrm{IN}} / \mathrm{C}_{\mathbf{P A H}}$ rose from a mean control value of 0.201 (range 0.157 to 0.253 ) to peak values averaging 0.333 (range 0.175 to 0.825 ).

Table II summarizes observations on the clearances of sodium $\left(\mathrm{C}_{\mathrm{Na}}\right)$, potassium $\left(\mathrm{C}_{\mathrm{K}}\right)$, chloride $\left(\mathrm{C}_{\mathrm{Cl}}\right)$ and phosphate $\left(\mathrm{C}_{\mathrm{PO}_{4}}\right)$ in these gouty subjects. Benemid was found to have negligible effects on $C_{K}$ and $C_{P_{4}}$ and on the ratios $C_{K} / C_{I N}$ and $\mathrm{C}_{\mathrm{PO}_{4}} / \mathrm{C}_{\mathrm{IN}}$; the mean per cent changes during the two-hour period following drug administration for $\mathrm{C}_{\mathrm{IN}}$ were $-4.3 \pm 2.1 \%$; for $\mathrm{C}_{\mathbf{K}} / \mathrm{C}_{\mathrm{IN}}$, $+0.7 \pm 8.1 \%$; for $\mathrm{C}_{\mathrm{PO}_{4}} / \mathrm{C}_{\mathrm{IN}},-2.6 \pm 5.9 \%$. The mean per cent changes for $\mathrm{C}_{\mathrm{Na}} / \mathrm{C}_{\mathrm{IN}}$ and $\mathrm{C}_{\mathrm{Cl}} / \mathrm{C}_{\mathrm{IN}}$ were of much greater magnitude, $+39.7 \pm 14.7 \%$ and $24.1 \pm 11.4 \%$, respectively. Statistical analysis indicates significant increases in both $\mathrm{C}_{\mathrm{Na}} / \mathrm{C}_{\mathrm{IN}}$ and $C_{\mathrm{Ol}} / \mathrm{C}_{\mathrm{IN}}$ ratios in four of the 12 subjects, a significant rise in $\mathrm{C}_{\mathrm{Na}} / \mathrm{C}_{\mathrm{IN}}$ only in a fifth subject, and in $\mathrm{C}_{\mathrm{Cl}} / \mathrm{C}_{\mathrm{IN}}$ only in a sixth subject after Benemid.

In the two patients so studied there were no significant effects of the drug upon urine or blood $\mathrm{pH}$, urine titratable acidity and ammonium ion excretion. However, these latter observations were obtained without previously rendering the subjects acidotic, and with low control values (2 to $10 \mu$ eq. hydrogen ion $/ \mathrm{min}$. and 10 to $19 \mu$ eq. ammonium ion/min.).

Prolonged experiments. Since the two-hour experiments lapsed before the uricosuric effect of Benemid had worn off, observations were prolonged over a 24-hour period in three gouty subjects in an attempt to establish the duration of increased $\mathrm{C}_{\text {URATE }}$ following ingestion of a single 2 gm. dose (Figure 1). The peak effect upon $\mathrm{C}_{\text {URate }} / \mathrm{C}_{\mathrm{IN}}$ or $\mathrm{C}_{\text {URate }} / \mathrm{C}_{\mathrm{CR}}$ ratios was found within the first four hours; in Case J. R. rising from a mean control ratio of 0.056 to 0.320 , in Case M. Mc. from 0.034 to 0.235 , and in Case J. F. from 0.058 to 0.225 . Significant elevations of these ratios persisted for 24 hours with a diurnal depression during sleeping hours. At the end of 24 hours the plasma urate concentrations had fallen from 7.9 to $5.1,8.4$ to 4.2 , and 8.2 to 4.1 mg. \%, respectively.

The results of a four-day study of the excretion of urate, water, sodium, potassium, chloride

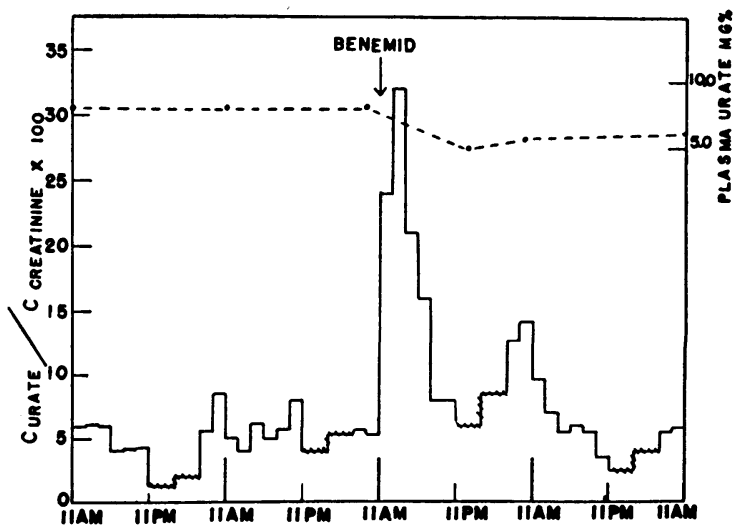

Fig. 2. Curate/Cor Ratios and Plasma Urate Concentrations in One Subject for 48 Hours Preceding and Following a Single 2 gm. Dose of Benemid While on a Constant Diet

The solid line represents the $\mathrm{C}_{\text {DRATr }} / \mathrm{C}_{\mathrm{CR}}$ ratios; the interrupted line plasma urate concentrations, and the crosshatches the sleeping hours. 
and creatinine in one gouty subject before and after a single dose of Benemid while on a controlled protein ( $50 \mathrm{gm}$.), constant salt (3.5 gm.), water $a d$ lib. regimen are presented in Figure 2. The subject was maintained on this constant diet for three days before obtaining the two-day preBenemid control data. The $\mathrm{C}_{\mathrm{URATE}} / \mathrm{C}_{\mathrm{CR}}$ ratios during the two control days and the second postmedication day showed diurnal depressions during sleeping hours similar to those while under Benemid influence. The 24-hour urate excretion rose to $1143 \mathrm{mg}$. from control values of 543 and $502 \mathrm{mg}$. This was associated with depression in the plasma urate concentration from a premedication value of $7.9 \mathrm{mg}$. $\%$ to $5.1 \mathrm{mg}$. \%, the greatest decrement occurring during the first four hours. There were no significant changes in the 24-hour excretion of sodium, potassium, chloride, water and creatinine following drug administration.

\section{DISCUSSION}

The current concept of renal mechanisms for urate excretion in normal man, recently summarized by Homer Smith (21), assumes complete filtration at the glomerulus and subsequent tubular reabsorption of all but a small fraction of the filtered urate, of which only 5-10\% appears in the urine. The tubular transport mechanisms for reabsorption of urate have been shown to be of limited capacity (22) with a Tmurate of approximately $15 \mathrm{mg} . / \mathrm{min}$., and, while not identified, are presumed to be enzymatic. There is no evidence for tubular secretion of urate in normal man, although this is known to occur in birds and reptiles.

In connection with the question of tubular secretion of urate in man, Praetorius and Kirk (23) report the case of a young man, in apparent good health, who was found to have a very low plasma urate $(0.2$ to $0.6 \mathrm{mg} . \%)$ associated with elevated $C_{\text {URATI }} / C_{\text {IN }}$ ratios averaging 1.46 . The authors interpreted these high ratios as indicating tubular secretion of urate. Although the renal clearance of urate undoubtedly was very high in this individual, the $\mathrm{C}_{\text {URATI }} / \mathrm{C}_{\text {IN }}$ ratios must be interpreted cautiously because of the analytical errors inherent in available methods for estimating such low plasma concentrations of urate and of inulin (9.03 to $9.77 \mathrm{mg} . \%$ ) as were present during their study. The plasma blank for inulin averages 1 to $2 \mathrm{mg}$./ml., $10-20 \%$ of the total plasma value.

We have had opportunity to study an unusual case of marked glomerulo-tubular imbalance of the Fanconi type, to be reported in detail elsewhere, which appears to throw light on this problem. In this subject $C_{I N}$ was markedly depressed $(26.1 \mathrm{ml} . / \mathrm{min}$.) but the functions attributed to proximal tubular activity were disproportionately and quite extraordinarily low: $C_{P A B} 36.7 \mathrm{ml} . / \mathrm{min}$., $T_{\text {PAI }} 4.9 \mathrm{mg}$. $/ \mathrm{min}$., Tma $22.0 \mathrm{mg} . / \mathrm{min}$. The plasma urate ( 2.3 to $2.8 \mathrm{mg} . \%$ ) was consistently below the normal range for the method we employ (4-6 mg.\% in males) yet the urate clearance was consistently elevated (C CRATE $25.7 \mathrm{ml} . / \mathrm{min}$. as compared with the normal of about $8 \mathrm{ml} . / \mathrm{min}$.) and the urinary urate excretion was about twice normal $(0.75 \mathrm{mg} . / \mathrm{min}$. instead of 0.30 to 0.40 $\mathrm{mg} . / \mathrm{min}$.).

In view of the indications of severe tubular damage in this patient, and the evidences of impaired reabsorption of glucose (renal glycosuria), amino acids (amino aciduria) and phosphate (hyperphosphaturia), it seemed more rational to ascribe the high urinary urate excretion to impaired tubular reabsorption of urate than to enhanced tubular secretion of urate. This interpretation was supported by the finding in this patient of a $\mathrm{C}_{\text {URATE }} / \mathrm{C}_{\mathrm{IN}}$ ratio of approximate unity (0.984), as compared with a normal mean $\mathrm{C}_{\text {ORATE }} / \mathrm{C}_{\mathrm{IN}}$ ratio of 0.067 , which would indicate both complete filtrability at the glomerulus and virtual absence of urate reabsorption by the tubules. In view of the concurrent evidence in this patient of generally reduced function of the proximal tubules, it may be inferred that urate normally is reabsorbed wholly or in large part by the proximal convoluted tubules. The fact that $\mathrm{C}_{\mathrm{URATE}} / \mathrm{C}_{\mathrm{IN}}$ did not exceed unity argues against tubular secretion of urate.

In accord with these inferences is the striking fact that of all the non-gouty and gouty subjects to whom we have administered Benemid, this patient was the only one in whom the drug failed to evoke increased urinary urate excretion and increased urate clearance.

The renal mechanisms for urate excretion in gouty subjects do not appear to differ in any essential from those of normal man $(24,25)$. However, in view of the often marked hyperuricemia in gout, complete filtrability of urate at the glomerulus cannot be assumed. We therefore subjected the sera of four of these patients, before treatment with Benemid, to ultrafiltration. The results, in conformity with those obtained in 13 other cases of gout (26), showed the serum urate to be wholly filtrable, apart from variations within the limits of error of the method: in case A. R., serum urate $11.3 \mathrm{mg}$. \% (expressed in terms of serum water), ultrafiltrate urate $11.6 \mathrm{mg}$. \%; in Case O. G., serum urate $11.1 \mathrm{mg}$. \%, ultrafiltrate $10.6 \mathrm{mg}$. \%; in Case M. M., serum urate 8.7 mg. $\%$, ultrafiltrate $8.8 \mathrm{mg}$. $\%$; in Case H. H., serum urate $8.5 \mathrm{mg}$. \%, ultrafiltrate $7.8 \mathrm{mg} . \%$. In view of these findings tubular reabsorption of 
urate and not non-filtrability of plasma urate must be assumed to explain the large discrepancy between urate clearance and glomerular filtration rate in these patients. The possibility of some tubular excretion of urate in gout is not excluded.

Saturation of tubule reabsorptive capacity for urate probably does not occur either in normal subjects (22) or in gouty patients with adequate renal function. According to Berliner, Hilton, Yü and Kennedy (22), a urate load/Tm URATE ratio of $1.25-1.50$ is necessary for saturation which, with a normal $T_{\text {URATE }}$ of $15 \mathrm{mg} . / \mathrm{min}$., would require filtered urate loads between 18.9 and $22.5 \mathrm{mg}$./min. - at a normal filtration rate of $120 \mathrm{ml} . / \mathrm{min}$. , necessitating plasma urate concentrations of $15.8-18.7 \mathrm{mg}$. \%. Since the filtration rate was depressed in most of our gouty patients, even higher plasma urate concentrations would be required. The greatest filtered urate load recorded in our gouty subjects was $14.5 \mathrm{mg} . / \mathrm{min}$. (Patient H. G., Table I). Moreover, no increase in $\mathrm{C}_{\text {URATE }} / \mathrm{C}_{\mathrm{IN}}$ ratios was observed in the patients with greater filtered urate loads, such as might be expected if significant tubule saturation had occurred.

There is every indication that, as in its effects on penicillin and p-aminosalicylic acid, Benemid produces uricosuria primarily by altering renal excretory mechanisms. The rapidity of the uricosuric effect, within 40 minutes of ingestion in most instances, makes it highly improbable that it can be accounted for by increased breakdown of nucleic acids, which normally have a slow turnover rate, or by accelerated urate biosynthesis. Moreover, studies carried out in two of our gouty subjects before, during and after ingestion of 2 gm. of Benemid showed no concurrent increase in urinary total nitrogen or phosphorus excretion (26). Bishop, Rand and Talbott (27) have demonstrated a decrease in the miscible pool of urate after administration of Benemid, indicating a predominantly excretory effect of the drug.

Our data indicate clearly that the enhancement of renal excretion of urate by Benemid is not due to an increase in glomerular filtration but is attributable to inhibition of tubular reabsorption of urate. In none of the subjects studied by us was this inhibition complete, the highest $\mathrm{C}_{\mathrm{URATE}} / \mathrm{C}_{\mathrm{IN}}$ ratio obtained being 0.547 . Since the drug exerts its effect upon known proximal tubule function (PSP, PAH, PAS and penicillin secretion) it appears likely that the uricosuric effect is mediated at this level of the nephron. It is interesting that the uricosuria produced by Benemid is the result of inhibition of a reabsorptive process whereas its other known effects are based upon inhibition of secretory mechanisms. The drug appeared to exert no effect upon phosphate reabsorption, the only other reabsorptive process with a Tm mechanism studied by us. Beyer and his associates (1), working with dogs, demonstrated that the drug exerted no effect upon the reabsorptive mechanisms for glucose, arginine, sulfonamides, urea and phosphate. The precise mechanism of the inhibitory effect of Benemid on tubular urate reabsorption has not been determined. According to Beyer and co-workers (1), the drug, in concentrations which suppress PAH, PSP, PAS, penicillin and urate transport, will inhibit utilization of energy from high-energy phosphate bonds without interfering with oxygen uptake or phosphorylation.

Significant depression of $\mathrm{C}_{\mathbf{P A B}}$ occurred following Benemid admininstration in eight of the 10 subjects so studied. From the data in Table I it is impossible to indicate to what extent these depressions resulted solely from inhibition of tubule secretory activity, since decrease in renal plasma flow might partially account for $\mathrm{C}_{\mathbf{P A B}}$ depressions. Quantitative evaluation of the effect of the drug upon this tubule function is possible only by $\mathrm{PAH}$ renal extraction and $T_{\mathrm{m}_{\mathbf{P A B}}}$ measurements. Beyer and his associates (1), employing Benemid in approximately twice the relative dosage used in our studies, were able to reduce $\mathrm{Tm}_{\mathrm{PAB}}$ to almost zero in dogs. In one non-gouty subject without renal disease studied by us, Benemid in a dose of $20 \mathrm{mg} . / \mathrm{kg}$. produced a fall of $T m_{P A H}$ from $83.4 \mathrm{mg}$./min. to $26.4 \mathrm{mg}$./min. without influencing $\mathrm{C}_{\mathrm{IN}}$, suggesting that the depressions in $\mathrm{C}_{\mathrm{PAB}}$ observed were primarily the result of inhibition of tubule secretory activity.

In the acute studies several of the subjects showed significant increases in the clearances of either sodium or chloride, or in both of these ions. However, the absolute magnitude of the renal clearances of these ions was so low that a slight increment would result in a marked increase in 
their clearance when expressed as per cent change. Thus, the maximum per cent change in $\mathrm{C}_{\mathrm{Na}} / \mathrm{C}_{\mathrm{IN}}$ noted, $130 \%$ (Case A. R., Table II), represents an actual increment of $\mathrm{C}_{\mathrm{Na}}$ from 1.05 to $2.60 \mathrm{ml}$./ min., and a change in urine excretion of 0.147 to $0.364 \mathrm{meq} . / \mathrm{min}$. The subjects who exhibited this increase in $\mathrm{C}_{\mathrm{Na}}$ and $\mathrm{C}_{\mathrm{Cl}}$ were among those who presented the most marked uricosuria. Significant water diuresis did not occur in these studies. However, the control urine flows before administration of the drug were maintained at high levels and may have masked a diuretic effect. The one subject studied on the controlled purine and salt intake and water $a d l i b$. failed to exhibit an increase in either salt or water output for the 24hour period following drug ingestion.

Beyer and co-workers (1) found that less than $2 \%$ of Benemid is excreted in dog's urine during 24 hours after a single intravenous dose, and that determinable plasma concentrations of the drug were present 48 hours after a single dose of 60 $\mathrm{mg} . / \mathrm{kg}$. They found that approximately $75 \%$ of the drug was bound to plasma protein and $25 \%$ was freely filtrable. This latter fraction is presumably filtered at the glomerulus and is virtually completely reabsorbed by the tubules. This provides an explanation for the prolonged uricosuric effect following a single dose of the drug. An oral dose of approximately $20 \mathrm{mg} . / \mathrm{kg}$. produced elevations of $C_{\text {URATE }} / G F R$ above control levels for 24 hours in the three subjects so studied. The complete tubular reabsorption of filtered Benemid presumably results in the maintenance of an effective concentration in or about the tubule cells for a prolonged period of time.

The diurnal variation of renal urate clearance noted in our cases is of some interest. Br $\phi$ chnerMortensen (28) reported a diurnal variation in urate clearances, with the lowest values occurring at night. Leathes (29) studied the diurnal urate excretion in a single individual on two different levels of purine ingestion and found decreased excretion during the sleeping hours on both levels of purine intake. Stanbury and Thomson (30) demonstrated a relatively greater depression of urate excretion than GFR in a single individual during sleeping hours. $\mathrm{C}_{\text {URATE }}$ was not determined in this subject. Since our studies demonstrated a fall in $\mathrm{C}_{\text {URATE}} / \mathrm{GFR}$ ratios at night, the decreased clearance of urate cannot be explained solely by the decreased glomerular activity which usually occurs at night (10). Benemid does not alter this diurnal pattern, even though the nocturnal $\mathrm{C}_{\text {URATE }}$ /GFR ratios, while under drug influence, are still higher than the control values. This pattern apparently reflects diurnal variation in tubule activity with respect to urate reabsorption. It is well established that a similar pattern occurs for the renal excretion of the major electrolytes and water (30).

Unless water diuresis is encouraged during Benemid uricosuria excessively high concentrations of urate may be encountered in the urine. Thus, in one of our subjects on the 24-hour study maintained on fluids ad lib., a concentration of urine urate of $157 \mathrm{mg}$. \% was obtained at a time when his urine flow was less than $1 \mathrm{ml} . / \mathrm{min}$. Talbott and Coombs (31) found a maximum urate solubility of slightly more than $100 \mathrm{mg} . / 100$ $\mathrm{ml}$. in the urine of gouty subjects. Alkalinization and water diuresis would therefore appear to be important measures for the prevention of uric acid crystalluria during Benemid therapy. In a gouty subject with normal glomerular function and a plasma urate concentration of $8 \mathrm{mg}$. \%, a urine flow of at least $4 \mathrm{ml} . / \mathrm{min}$. is necessary to maintain urine urate concentrations under 100 mg. $/ 100 \mathrm{ml}$. during the peak of Benemid uricosuria, which occurs within four hours after drug administration.

No indication of toxicity attributable to Benemid was observed in the course of these experiments, with the possible exception of one patient who developed an acute attack of gout the day after. The effects upon renal transport mechanisms are completely reversible following discontinuance of medication. Benemid appears thus far to be of a low order of toxicity $(6,32)$ and no overt signs of renal "irritation" (albuminuria, casts, red blood cells) unequivocally attributable to the drug have yet been reported.

\section{SUMMARY}

1. In 15 clearance studies carried out in 13 gouty subjects, Benemid given orally in a single $2 \mathrm{gm}$. dose consistently produced a marked rise in urate clearance, from a mean control level of $7.99 \mathrm{ml} . / \mathrm{min}$. to a mean peak value of $32.7 \mathrm{ml}$./ 
min. This rise was usually evident within 40 minutes of drug administration and lasted 24 hours in the subjects followed for this period. The plasma urate level fell concomitantly.

2. There was no significant effect on glomerular filtration rate. The ratio $C_{\text {URATE}} / G F R$ consequently rose, from a mean control value of 0.0718 to peak values averaging 0.333 .

3. Some depression of $\mathrm{C}_{\mathrm{PAH}}$, with consequent moderate rise in the ratio $\mathrm{C}_{\mathrm{IN}} / \mathrm{P}_{\mathrm{PAH}}$, was observed in most instances.

4. Phosphate and potassium clearances were unaffected by Benemid. Slight but significant increases in sodium or chloride clearance, or both, occurred in about half the subjects.

5. A marked diurnal variation in $\mathrm{C}_{\text {URATE}} / \mathrm{GFR}$ ratios was noted in those subjects in whom these functions were studied over one or more 24-hour periods. The depression of these ratios noted during sleeping hours persisted in spite of continued overall Benemid uricosuria.

6. The data obtained support the complete filtration-partial tubular reabsorption concept of urate excretion in the normal and gouty subject and indicate that Benemid uricosuria is the result of a highly selective inhibition of tubular reabsorption of filtered urate. Corroboratory evidence for this conclusion was derived by clearance studies in one subject with glomerulo-tubular imbalance of the Fanconi type who was found to have a $\mathrm{C}_{\mathrm{URATE}} / \mathrm{C}_{\mathrm{IN}}$ ratio of approximate unity, which was uninfluenced by Benemid.

\section{ACKNOWLEDGMENTS}

We are deeply indebted to Sharp and Dohme, Inc., for the generous supply of Benemid used in these studies, and to Miss Gertrude Chesin and Mr. Edward Jaffe for their valuable technical assistance.

\section{REFERENCES}

1. Beyer, K. H., Russo, H. F., Tillson, E. K., Miller, A. K., Verwey, W. F., and Gass, S. R., "Benemid," p-(di-n-propylsulfamyl)-benzoic acid: its renal affinity and its elimination. Am. J. Physiol., 1951, $166,625$.

2. Burnell, J. M., and Kirby, W. M. M., Effectiveness of a new compound, Benemid, in elevating serum penicillin concentrations. J. Clin. Invest., 1951, 30, 697.

3. Beyer, K. H., Functional characteristics of renal transport mechanisms. Pharmacol. Reviews, 1950, $2,227$.
4. Boger, W. P., Beatty, J. O., Pitts, F. W., and Flippin, $H$. F., The influence of a new benzoic acid derivative on the metabolism of $\mathbf{p}$-aminosalicylic acid (PAS) and penicillin. Ann. Int. Med., 1950, 33, 18.

5. Gutman, A. B., in Combined Staff Clinic on Uric acid metabolism and gout. Am. J. Med., 1950, 9, 799.

6. Gutman, A. B., and Yü, T. F., Benemid (p-[di-npropylsulfamyl]-benzoic acid) as uricosuric agent in chronic gouty arthritis. Tr. A. Am. Physicians, 1951, 64, 279.

7. Talbott, J. H., Bishop, C., Norcross, B. M., and Lockie, L. M., The clinical and metabolic effects of "Benemid" in patients with gout. Tr. A. Am. Physicians, 1951, 64, 372.

8. Gutman, A. B., Gout, a derangement of purine metabolism, in Advances in Internal Medicine. Interscience Publishers, Inc., New York, 1951, Vol. V, in press.

9. Goldring, W., and Chasis, H., Hypertension and $\mathrm{Hy}-$ pertensive Disease. The Commonwealth Fund, New York, 1944.

10. Sirota, J. H., Baldwin, D. S., and Villarreal, H., Diurnal variations of renal function in man. $\mathrm{J}$. Clin. Invest., 1950, 29, 187.

11. Schreiner, G. E., Determination of inulin by means of resorcinol. Proc. Soc. Exper. Biol. \& Med., 1950, 74, 117.

12. Smith, H. W., Finkelstein, N., Aliminosa, L., Crawford, B., and Graber, M., The renal clearances of substituted hippuric acid derivatives and other aromatic acids in dog and man. J. Clin. Invest., 1945, 24, 388.

13. Bonsnes, R. W., and Taussky, H. H., On the colorimetric determination of creatinine by the Jaffé reaction. J. Biol. Chem., 1945, 158, 581.

14. Fiske, C. H., and SubbaRow, Y., The colorimetric determination of phosphorus. J. Biol. Chem., 1925, $66,375$.

15. Schales, O., and Schales, S. S., A simple and accurate method for determination of chloride in biological fluids. J. Biol. Chem., 1941, 140, 879.

16. Van Slyke, D. D., and Hiller, A., Application of Sendroy's iodometric chloride titration to proteincontaining fluids. J. Biol. Chem., 1947, 167, 107.

17. Van Slyke, D. D., and Cullen, G. E., The mode of action of urease and of enzymes in general. J. Biol. Chem., 1914, 19, 141.

18. Pitts, R. F., and Alexander, R. S., The nature of the renal tubular mechanism for acidifying the urine. Am. J. Physiol., 1945, 144, 239.

19. Buchanan, O. H., Block, W. D., and Christman, A. A., The metabolism of the methylated purines. I. The enzymatic determination of urinary uric acid. J. Biol. Chem., 1945, 157, 181.

20. Simms, H. S., and Sanders, M., Use of serum ultrafiltrate in tissue cultures for studying the deposition of fat and for propagation of viruses. Arch. Path., 1942, 33, 619. 
21. Smith, H. W., The Kidney: Structure and Function in Health and Disease. Oxford University Press, New York, 1951.

22. Berliner, R. W., Hilton, J. G., Yü, T. F., and Kennedy, T. J., Jr., Renal mechanisms for urate excretion in man. J. Clin. Invest., 1950, 29, 396.

23. Praetorius, E., and Kirk, J. E., Hypouricemia : with evidence for tubular elimination of uric acid. J. Lab. \& Clin. Med., 1950, 35, 865.

24. Talbott, J. H., Gout. Oxford University Press, New York, 1943.

25. Friedman, M., and Byers, S. O., Increased renal excretion of urate in young patients with gout. Am. J. Med., 1950, 9, 31.

26. Yü, T. F., Unpublished data.

27. Bishop, C., Rand, R., and Talbott, J. H., The effect of Benemid (p-[di-n-propylsulfamyl]-benzoic acid) on uric acid metabolism in one normal and one gouty subject. J. Clin. Invest., 1951, 30, 889.

28. Brøchner-Mortensen, $K$., The uric acid content in blood and urine in health and disease. Medicine, 1940, 19, 161.

29. Leathes, J. B., On diurnal and nocturnal variations in the excretion of uric acid. J. Physiol., 1906-7, $35,125$.

30. Stanbury, S. W., and Thomson, A. E., Diurnal variations in electrolyte excretion. Clin. Science, 1951, 10, 267.

31. Talbott, J. H., and Coombs, F. S., Metabolic studies on patients with gout. J.A.M.A., 1938, 110, 1977.

32. Boger, W. P., and Strickland, S. C., Benemid: Preliminary assessment of its toxicity in man. $\mathrm{Tr}$. Tenth Veterans Administration, Army-Navy Conference on the Chemotherapy of Tuberculosis, Atlanta, Georgia, 1951. 